\title{
Rock type leaves topographic signature in landslide-dominated mountain ranges
}

Oliver Korup ${ }^{1}$

Received 28 March 2008; accepted 2 May 2008; published 10 June 2008.

[1] The idea that hillslopes in active mountain belts are limited to a threshold inclination by the rate of landsliding has guided landscape evolution models for over a decade. However, widely applied topographic diagnostics of threshold hillslopes remain debated and unverified. This study relates landslide occurrence to hillslope metrics of several active mountain ranges throughout New Zealand, which are formed in uniform greywacke and its schist derivative. All these ranges share a distinctive peak in hillslope inclination despite order-of-magnitude variations in rates of rock uplift and precipitation, landslide density, and extent of Quaternary glaciation. Comparison with landslide-dominated terrain in different lithologies highlights this peak as diagnostic of rock type, reflecting a conspicuous tendency in hillslope evolution to adjust to rockmass strength irrespective of the intensity of tectonic and climatic forcing. This finding expands the model perspective that only undisturbed strength-equilibrium slopes may adjust to their rock-mass strength. Citation: Korup, O. (2008), Rock type leaves topographic signature in landslide-dominated mountain ranges, Geophys. Res. Lett., 35, L11402, doi:10.1029/ 2008 GL034157.

\section{Introduction}

[2] Recent development of mechanistic theories of erosion in tectonically active mountain belts has focused on fluvial bedrock incision [Whipple et al., 1999], whereas few theories predict in comparable sophistication processes and rates of hillslope erosion. This is surprising, given that hillslopes strikingly dominate mountainous landscapes. Models of landscape evolution of active mountain belts have embraced the idea that hillslopes adjust to rapid fluvial bedrock incision through increased rates of landsliding rather than gradual steepening. Burbank et al. [1996] highlighted the uniformity of slope-angle histograms of the northwestern Himalayas across regional gradients in long-term rates of rock uplift and erosion of $1-12 \mathrm{~mm} \mathrm{yr}^{-1}$. They concluded that pervasive landsliding in response to rapid bedrock river incision led to the development of threshold hillslopes inclined at their angle of internal friction. Implicit to this idea is that cohesion is negligible in hillslope adjustment, and that hillslope height and topographic relief are limited by rock-mass strength [Schmidt and Montgomery, 1995; Montgomery and Brandon, 2002]. A corollary is that landslide-supplied sediment flux increases nonlinearly with hillslope inclination toward an

\footnotetext{
${ }^{1}$ Research Department Avalanches, Debris Flows, and Rock Falls, Swiss Federal Research Institutes WSL/SLF, Davos, Switzerland.

Copyright 2008 by the American Geophysical Union. 0094-8276/08/2008GL034157
}

asymptotic threshold value to maintain angle-of-repose slopes [Howard, 1997].

[3] Threshold hillslopes have been reported from several tectonically active mountain belts including the Olympic Mountains [Montgomery, 2001], the Tibetan Plateau margin [Whipple et al., 1999], the Tien Shan [Sobel et al., 2006], and the Bolivian Andes [Safran et al., 2005]. However, there are no unambiguous morphometric indicators of threshold hillslopes [Montgomery, 2001], and identification has relied on indirect evidence such as slope-angle histograms [Burbank et al., 1996], or the invariance of mean slope angle with respect to inferred rates of bedrock river incision [Safran et al., 2005]. Few studies have afforded any verifying landside data as rate constraints, while causal, let alone mechanistic, links between patterns of landsliding, lithology, and threshold hillslopes remain to be tested [Montgomery, 2001]. This lack of empirical tests means that very little is known about the minimum requirements for threshold hillslopes to develop. For example, Binnie et al. [2007] suggested that threshold hillslopes in the Transverse Mountains of California had formed at rates of rock uplift and erosion as low as $0.2-2 \mathrm{~mm} \mathrm{yr}^{-1}$. In contrast, Korup and Schlunegger [2007] reported that in the eastern Swiss Alps, where rates of rock uplift are comparable, threshold hillslopes mainly occur along inner gorges in the lowermost $25 \%$ of topographic relief.

\section{Topographic Fingerprint of Rock Type and Landslides}

[4] This study seeks to explore relationships between (threshold) hillslope distributions, present-day landslide occurrence, and rock type in tectonically active mountain ranges of New Zealand that straddle most of the country's long axis (Figure 1a). Investigating those parts of the ranges that are underlain by indurated, interbedded mudstones and muddy sandstones, i.e. greywacke of Upper Paleozoic to Mesozoic age and its metamorphic schist facies [Read et al., 2000; Norris and Cooper, 2000] helps elucidate how varying intensity of tectonic and climatic forcing affects regional-scale hillslope inclination in uniform rock type.

[5] Montgomery [2001] provided the background information for the methodology used in this paper. Two hillslope metrics, i.e. slope angle $\beta$ and slope gradient $S=\tan \beta$ were considered in order to avoid potential bias due to nonlinear binning, and computed by fitting a plane to a moving $3 \times 3$ window in a digital elevation model (DEM) of $25-\mathrm{m}$ grid resolution. Sampled areas comprised ten $25-\mathrm{km}^{2}$ squares arbitrarily placed in the core of each individual mountain range, where valley fills and glaciers are negligible, and lithology considered uniform (Figure 1a). Probability density plots of $\beta$ and $S$ are slightly skewed and 
(a)
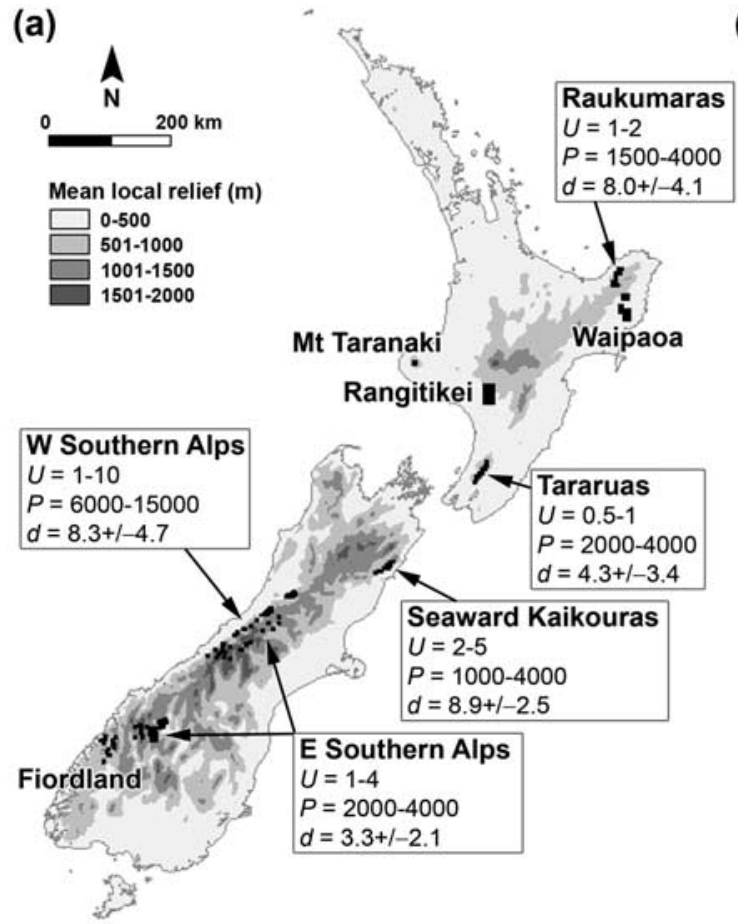

(b)
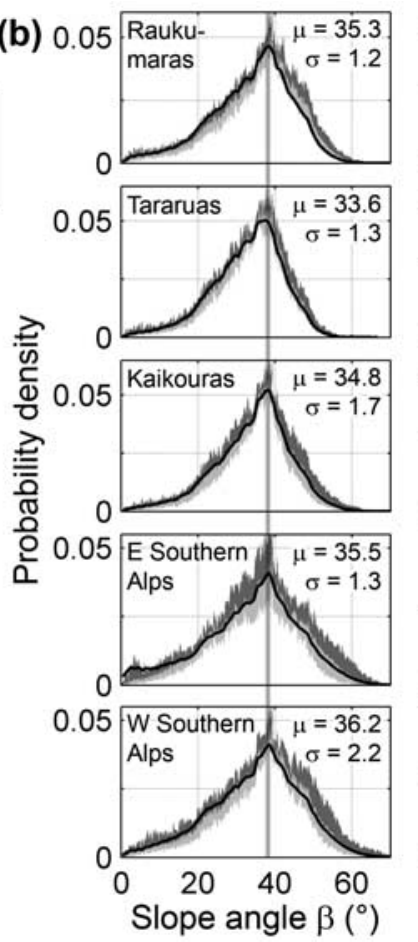

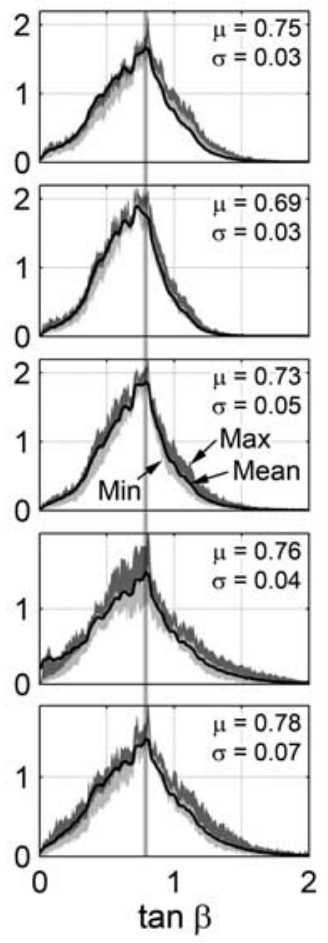

Figure 1. (a) Map of studied mountain ranges in uniform greywacke (boxes). Mean local relief $\hat{H}$ is maximum difference of GTOPO30 elevation data within 5-km radius [Montgomery and Brandon, 2002]. $U$ and $P$ are rates of rock uplift and mean annual precipitation, respectively $\left[\mathrm{mm} \mathrm{yr}^{-1}\right] ; d$ is mean contemporary landslide density $\left[\mathrm{km}^{-2}\right]( \pm 1$ standard deviation $\sigma$ ). (b) Probability density plots of hillslope metrics obtained for area of each mountain range with $\hat{H}>300 \mathrm{~m}$ (black curves with mean $\mu$ and $\sigma$ ). Light (dark) gray area is minimum (maximum) deviation from pooled mean of ten $25-\mathrm{km}^{2}$ sample squares in each mountain range (black areas in Figure 1a). Vertical lines highlight uniform modes despite order-of-magnitude variations in $U, P$, and varying $d$.

intermittent in shape. None of them are normally distributed $(p=0.05)$; hence they differ from distributions of other mountain belts where threshold hillslopes have developed [Montgomery, 2001] (Figure 1b). However, all distributions share a common and distinctive peak $\hat{S} \sim 0.78$ despite orderof-magnitude variations in rates of rock uplift, precipitation, landslide density, and area affected by Quaternary glaciation [Whitehouse and Pearce, 1992].

[6] This strikingly uniform peak varies with rock type in other areas that are similarly dominated by river and landslide erosion (Figure 2). Granites and gneisses of the crystalline basement of the Fiordland mountains with a higher rock-mass strength than greywacke [Augustinus, 1995] show a slightly higher value of $\hat{S}$. Conversely, the landslide-prone and markedly weaker Upper Tertiary siltand mudstones of the Waipaoa catchment [Reid and Page, 2002] show significantly lower peaks in $\beta$ and $S$ than the greywacke ranges. Modal values lower than those of greywacke also characterize Pliocene marine sand- and siltstones of the highly dissected and landslide-dominated upper Rangitikei River basin [Crozier and Pillans, 1991], as well as Quaternary volcanics of the Mt Taranaki edifice [Alloway et al., 2005].

[7] In order to explore the effects of landslides, the locations of 8720 contemporary (i.e. $<20$ yr-old) landslide scars in five of the greywacke ranges were mapped from orthophotos over a total sample area of $1354 \mathrm{~km}^{2}$ (Figure 1b), and used to estimate landslide density within a kernel of 1-km radius. This dataset chiefly consists of shallow soil and debris slides and flows. The resulting landslide densities are $<10 \mathrm{~km}^{-2}$, while some clusters $\left(<40 \mathrm{~km}^{-2}\right)$ are limited to $<5 \%$ of the area mapped (Figure 3a), assuming that $>95 \%$ of all landslides were detected. Particularly the Southern Alps also host at least 80 larger deep-seated landslides that mobilized $>10^{7} \mathrm{~m}^{3}$ and have failure depths $>10 \mathrm{~m}$ [Korup, 2006]. Although not as abundant as their shallow counterparts, these landslides cause a systematic decrease in mean slope gradient $S_{\mu}$ particularly where they involve little displacement of rock mass because of low strain rates (Figure $3 b$ ). Given that neither $\hat{S}$ nor $S_{\mu}$ correlates with the rate of rock uplift (Figures $1 \mathrm{~b}$ and $4 \mathrm{a}$ ), threshold topography seems to have been attained in the ranges studied. Higher rates of rock uplift seem to be countered by higher mean landslide densities, and on average $55 \%$ of all mapped landslides initiate above $\hat{S}$ (Figures $4 \mathrm{~b}$ and $4 \mathrm{c}$ ).

\section{Implications for Hillslope Evolution}

[8] Rock type is the only unifying characteristic in the mountain ranges studied (Figure 1). Thus the nearly uniform mode in their hillslope distributions is the "common threshold" [Burbank et al., 1996], which is interpreted here as a proxy of rock type and, more specifically, rock strength. Where large deep-seated landslides abound, rock masses 

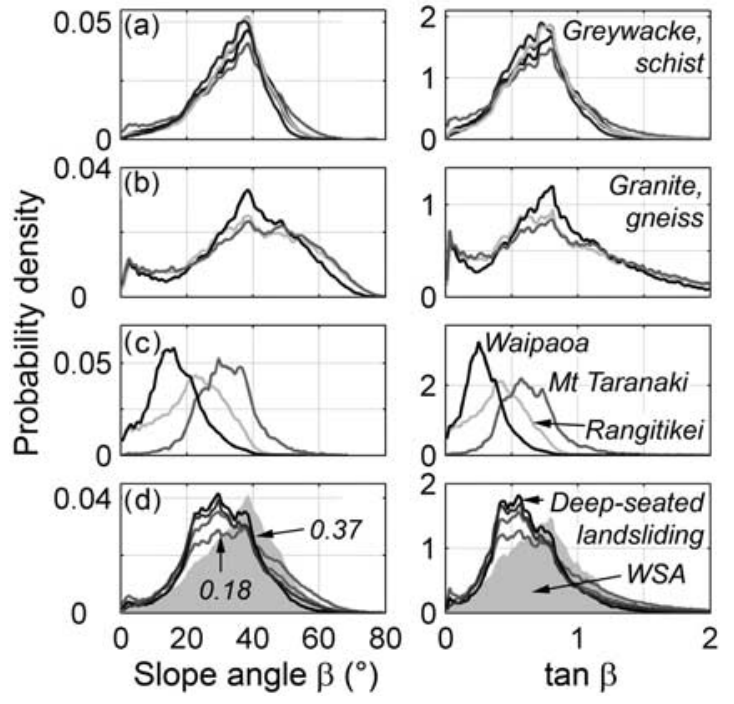

Figure 2. Topographic fingerprint of rock type and deepseated landslides on hillslope metrics of landslide-dominated terrain (Figure 1a). (a) Greywacke and schist ranges. (b) Basement granites and gneisses, Fiordland mountains. (c) Upper Tertiary sand- and mudstones (Waipaoa and upper Rangitikei River); Quaternary volcanics (Mt Taranaki). (d) Deep-seated landsliding (curves) in schists of western Southern Alps (gray shaded, WSA); inset figures are estimated fraction of terrain affected by deep-seated landslides.

have deteriorated from peak to residual strength during displacement associated with rock fracturing and loss of internal friction. This significantly biases mean slope gradient $S_{\mu}$ as a widely used indicator of threshold hillslopes [Safran et al., 2005; Sobel et al., 2006], which may be even less reliable in terrain composed of different rock types. Clearly, the invariance of $S$ with respect to tectonic and climatic forcing serves as a more appropriate diagnostic of rock-type controlled threshold topography in landslidedominated mountain ranges. This requires that $\hat{S}$ approximate the dominant internal angle of friction $\phi$ of greywacke [Carson and Petley, 1969], acknowledging any underestimates due to DEM resolution. Intact New Zealand greywacke is strong (uniaxial compressive strength $>250 \mathrm{MPa}$ ), although commonly densely jointed. Read et al. [2000] cautioned that the spacing of rock-mass defects eventually sets the lower boundary for slope stability and showed that samples of very low strength have values of up to $\phi=48^{\circ}$ at an apparent cohesion $c^{\prime}=0 \mathrm{kPa}$. Only the Southern Alps host a significant number of oversteepened slopes with comparable mean values of $\beta \sim 45^{\circ}$ to $47^{\circ}$, whereas slopes in the other mountain ranges are generally less steep, though still at their threshold (Figures 1 and $4 a$ ). This implies that the probability density of hillslope metrics at least partly mirrors a range of values rather than a single value of $\phi$, which is most likely controlled by the distribution of the spacing of rock-mass defects. Such distributions often approximate power-law models [Bonnet et al., 2001], which may explain the conspicuous decay of slope values $S>\hat{S}$ (Figure 1).
[9] Effectively friction-controlled hillslopes should thus vary in steepness, which is supported by the counterintuitive trend of landslide density to level out - or at least not significantly increase-for $S>\hat{S}$ (Figures 3a and 4b). This trend contradicts the idea that the steepest hillslopes are maintained to their effective strength by a significantly higher rate of landsliding only if assuming a single internal friction, or threshold hillslope, angle [Burbank et al., 1996]. In the Seaward Kaikouras, this trend can be explained by likely undersampling of landslides on bare rock slopes, which are often subject to shadow and patchy snow-cover effects, and contrast-poor source areas of rock-slope fail-
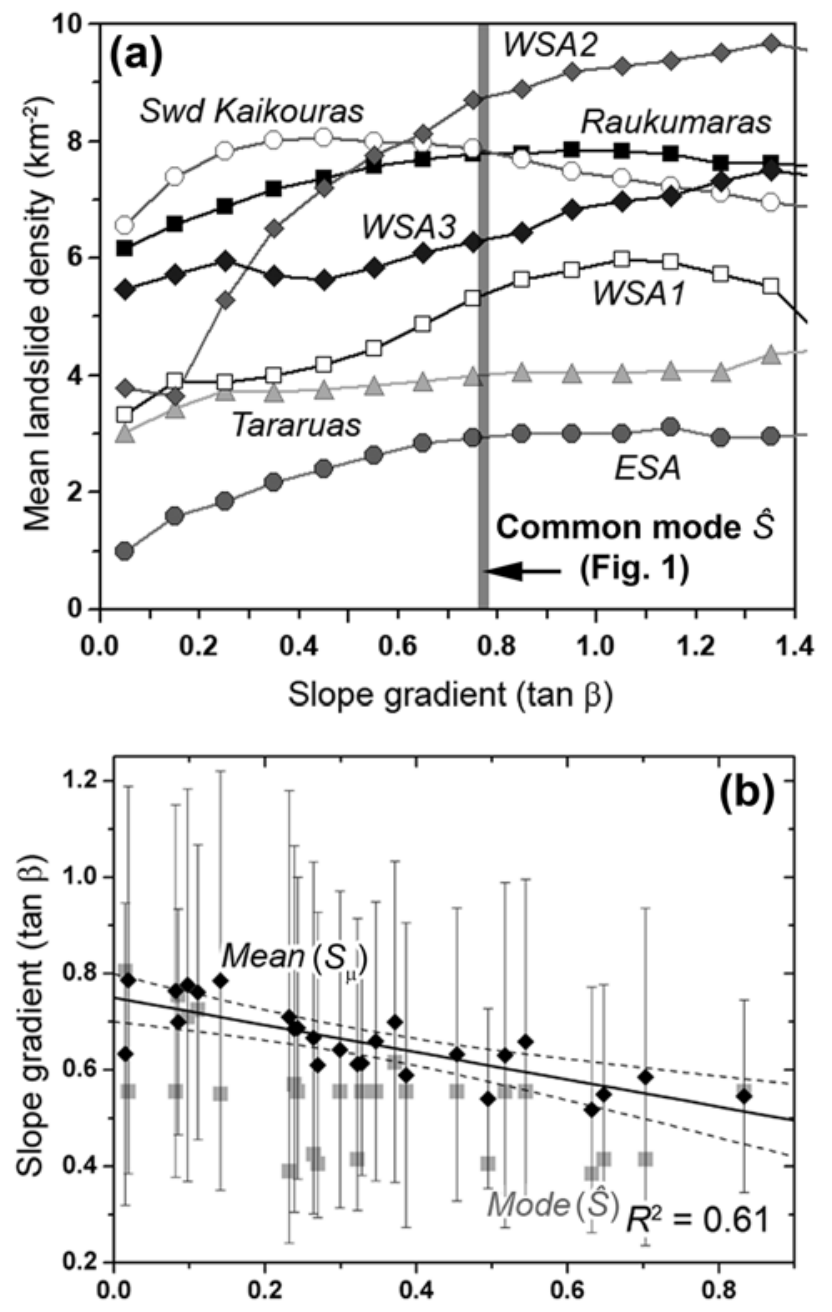

Fraction of landscape affected by deep-seated landslides

Figure 3. (a) Mean contemporary landslide density in relation to slope gradient $S$. Data cover $>95 \%$ of mapped area in each mountain belt exclusive of flattest and steepest terrain. The linear increase in landslide density $(p<0.005)$ declines significantly above the common mode $\hat{S}$. WSA, ESA = western and eastern Southern Alps of New Zealand, respectively. (b) Effect of large deep-seated landslides on $S$ in 25-km ${ }^{2}$ sample squares, Southern Alps ( $\pm 1 \sigma$ error bars). Black solid line is linear fit $(p<0.005)$ with $99 \%$ confidence intervals (dashed). Intercept coincides with values of $S_{\mu}$ in areas with negligible deep-seated landsliding. 


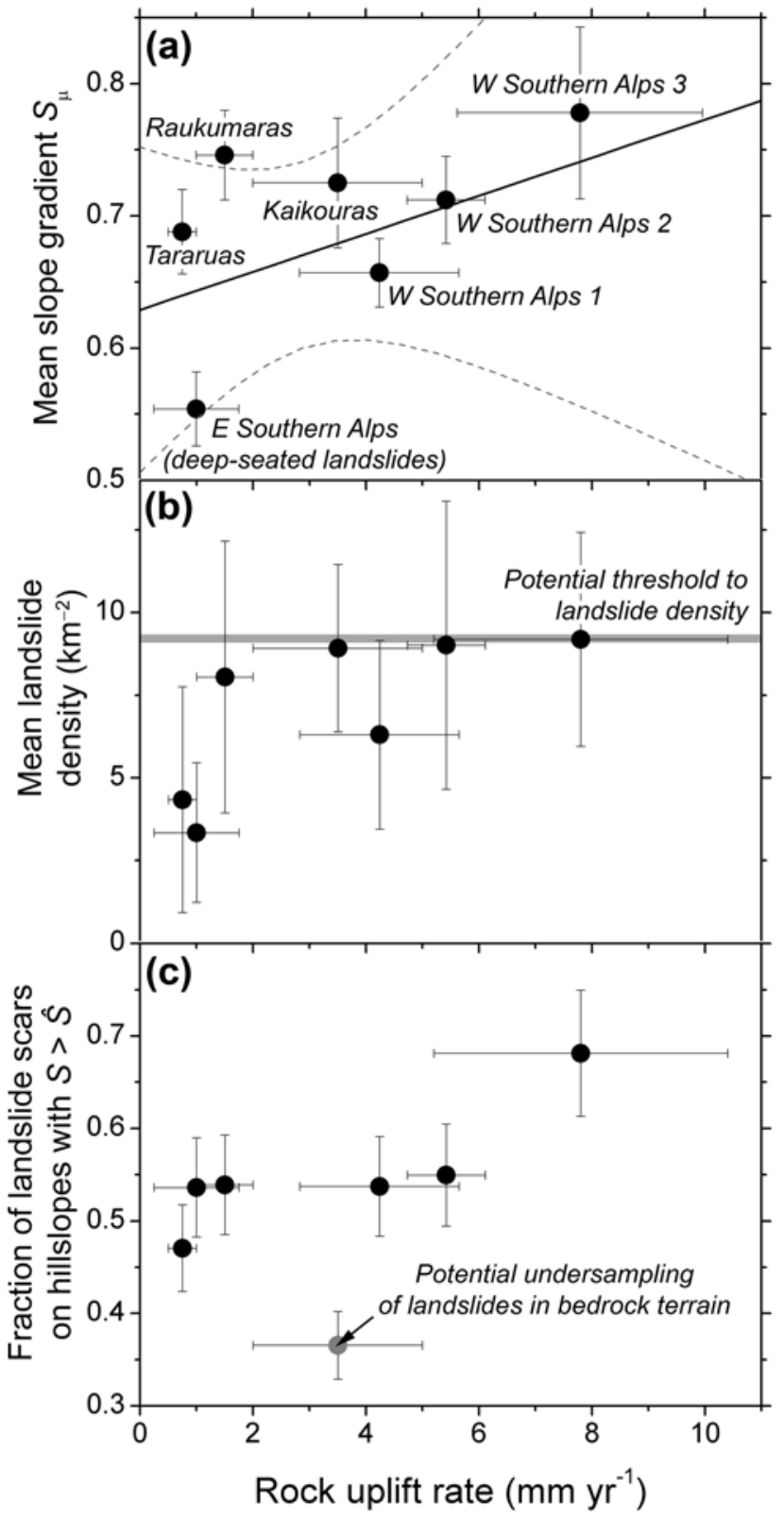

Figure 4. (a) Mean slope gradient $S_{\mu}$ in relation to rates of rock uplift $U$ in mountain ranges of New Zealand $( \pm 1 \sigma$ error bars). Error-weighted linear fit with dashed $95 \%$ confidence intervals has regression slope $a=0.014 \pm 0.014(p>0.34)$, indicating that differences in $S_{\mu}$ are statistically not significant despite varying $U$. This is a quantitative argument for threshold hillslopes. (b) Mean landslide density increases with $U$ and reaches a potential threshold value of $\sim 9 \mathrm{~km}^{-2}$ ( $\pm 1 \sigma$ error bars). (c) Fraction of landslides $( \pm 10 \%$ error bars) initiating above $\hat{S}$ moderately scales with $U(p<0.05)$.

ures. However, the density of mostly shallow landslides may simply reflect residual strength characteristics of soil and colluvium rather than that of bedrock. Steeper hillslopes are likely to become weathering-limited as the rate of landslide denudation eventually outpaces that of soil for- mation, thus starving out the potential for soil and debris slides. It is equally likely, however, that the lack of significant rate increase above $\hat{S}$ is compensated for by larger landslide size [Korup et al., 2007]. At least, all seven of the post-1990 catastrophic landslides $>10^{6} \mathrm{~m}^{3}$ in the Southern Alps occurred on hillslopes steeper than $45^{\circ}$.

[10] The apparent correlation between rates of rock uplift and the density and location of contemporary landslides is also surprising (Figure 4), as these may not necessarily signify long-term erosion rates. Earthquake- or rainfalltriggered landsliding episodes may bias the present landsliding pattern, giving the impression of high erosional activity in landscapes remaining otherwise mostly dormant for the time between such events [Korup, 2006]. Yamagishi and Iwahashi [2007] reported an exponential growth of the density of earthquake-triggered landslides with mean slope angle in the Niigata region of Japan, as opposed to a more linear trend for rainfall-triggered landslides. A similar relationship between landslide density and $S$ in nearly all the New Zealand ranges studied supports the notion of rainfall as a trigger (Figure 3a). This is plausible, as there have been no recent major landslide-triggering earthquakes in these ranges [Korup, 2005]. Whatever the recurrence intervals of such landsliding episodes may be, the presentday distribution of landslides must indicate to some extent spatial gradients in susceptibility to slope failure as a function of gradual loss of excess shear strength.

\section{Conclusions and Scope}

[11] Modal slope inclination is a promising proxy of dominant rock-mass strength in landslide-dominated threshold topography of uniform lithology. Future work is necessary to attempt a calibration between field derived rockmass parameters and their topographic signature. However, the methodology proposed here does not claim to comprehensively explain the full spectrum of linkages between landsliding, rock type, and threshold topography. Yet even if accepting the unlikely notion that the greywacke and schist ranges of New Zealand have undergone identical tectonic and erosional histories during the last few million years, results show that hillslope evolution nonetheless tends toward a common topographic signature of rock type and strength despite order-of-magnitude variations in tectonic and climatic forcing. This finding expands the classic model of strength-equilibrium rock slopes that adjust their inclination to their rock-mass strength only if no external disturbance such as frequent slope undercutting or landsliding occurs [Selby, 1982]. Litho- and biostratigraphy provide upper constraints to the time necessary to develop threshold hillslopes, as some of the axial greywacke ranges in New Zealand are capped by Pliocene marine limestones $<3 \mathrm{Myr}$ old [Litchfield and Berryman, 2006]. Hence threshold topography is attainable on $10^{6}$-yr timescales at uplift rates as low as $0.5 \mathrm{~mm} \mathrm{yr}^{-1}$. Sobel et al. [2006] proposed a comparable timescale of threshold-hillslope formation in the Kyrgyz Tien Shan, while Korup and Schlunegger [2007] argued that incipient threshold hillslope formation in the lower parts of alpine valley relief may occur on glacial/ interglacial (i.e., $10^{5}$-yr) timescales. This underscores the range of process rates and environments in which one is likely to encounter threshold hillslopes. 
[12] Acknowledgments. Comments by M. McSaveney, T. R. Davies, N. Hovius, two anonymous reviewers, and one AE are well appreciated. Funded by EU-FP6 Grant 018412 "IRASMOS".

\section{References}

Alloway, B., P. McComb, V. Neall, C. Vucetich, J. Gibb, S. Sherburn, and M. Stirling (2005), Stratigraphy, age, and correlation of voluminous debris-avalanche events from an ancestral Egmont Volcano: Implications for coastal plain construction and regional hazard assessment, $J . R$. Soc. N. Z., 35, 229-267.

Augustinus, P. A. (1995), Glacial valley cross-profile development: The influence of in situ rock stress and rock mass strength, with examples from the Southern Alps, New Zealand, Geomorphology, 14, 87-97.

Binnie, S. A., W. M. Phillips, M. A. Summerfield, and L. K. Fifield (2007), Tectonic uplift, threshold hillslopes, and denudation rates in a developing mountain range, Geology, 35, 743-746.

Bonnet, E., O. Bour, N. E. Odling, P. Davy, I. Main, P. Cowie, and B. Berkowitz (2001), Scaling of fracture systems in geological media, Rev. Geophys., 39, 347-383.

Burbank, D. W., J. Leland, E. Fielding, R. S. Anderson, N. Brozovic, M. R. Reid, and C. Duncan (1996), Bedrock incision, rock uplift, and threshold hillslopes in the northwestern Himalaya, Nature, 379, 505-510.

Carson, M. A., and D. J. Petley (1969), The existence of threshold hillslopes in the denudation of the landscape, Trans. Inst. Brit. Geogr., 49, $71-95$.

Crozier, M. J., and B. J. Pillans (1991), Geomorphic events and landform response in south-eastern Taranaki, New Zealand, Catena, 18, 471-487.

Howard, A. D. (1997), Badland morphology and evolution: Interpretation using a simulation model, Earth Surf. Processes Landforms, 22, $211-$ 227.

Korup, O. (2005), Distribution of landslides in southwest New Zealand, Landslides, 2, 43-51.

Korup, O. (2006), Effects of large deep-seated landslides on hillslope morphology, western Southern Alps, New Zealand, J. Geophys. Res., 111, F01018, doi:10.1029/2004JF000242.

Korup, O., and F. Schlunegger (2007), Bedrock landsliding, river incision, and transience of geomorphic hillslope-channel coupling: Evidence from inner gorges in the Swiss Alps, J. Geophys. Res., 112, F03027, doi:10.1029/2006JF000710.

Korup, O., J. J. Clague, R. L. Hermanns, K. Hewitt, A. L. Strom, and J. T. Weidinger (2007), Giant landslides, topography, and erosion, Earth Planet. Sci. Lett., 261, 578-589.
Litchfield, N., and K. Berryman (2006), Relationship between postglacial fluvial incision rates and uplift rates in the North Island, New Zealand, J. Geophys. Res., 111, F02007, doi:10.1029/2005JF000374.

Montgomery, D. R. (2001), Slope distributions, threshold hillslopes, and steady-state topography, Am. J. Sci., 301, 432-454.

Montgomery, D. R., and M. T. Brandon (2002), Topographic controls on erosion rates in tectonically active mountain belts, Earth Planet. Sci. Lett., 201, 481-489.

Norris, R. J., and A. F. Cooper (2000), Late Quaternary slope rates and slip partitioning on the Alpine Fault, New Zealand, J. Struct. Geol., 23, 507520.

Read, S. A. L., L. Richards, and N. D. Perrin (2000), Assessment of New Zealand greywacke rock masses with the Hoek-Brown failure criterion, in Proceedings GeoEng 2000 International Conference on Geotechnical and Geological Engineering, Melbourne, 2000, vol. 2, p. 20, A. A. Balkema, Rotterdam, Netherlands.

Reid, L. M., and M. J. Page (2002), Magnitude and frequency of landsliding in a large New Zealand catchment, Geomorphology, 49, 71-88.

Safran, E. B., P. R. Bierman, R. Aalto, T. Dunne, K. X. Whipple, and M. Caffee (2005), Erosion rates driven by channel network incision in the Bolivian Andes, Earth Surf. Processes Landforms, 30, 1007-1024.

Schmidt, K. M., and D. R. Montgomery (1995), Limits to relief, Science, $270,617-620$.

Selby, M. J. (1982), Controls on the stability and inclination of hillslopes formed on hard rock, Earth Surf. Processes Landforms, 7, 449-467.

Sobel, E. R., M. Oskin, D. Burbank, and A. Mikolaichuk (2006), Exhumation of basement-cored uplifts: Example of the Kyrgyz Range quantified with apatite fission track thermochronology, Tectonics, 25, TC2008, doi:10.1029/2005TC001809.

Whipple, K. X., E. Kirby, and S. H. Brocklehurst (1999), Geomorphic limits to climate-induced increases in topographic relief, Nature, 401, $39-43$.

Whitehouse, I. E., and A. J. Pearce (1992), Shaping the mountains of New Zealand, in Landforms of New Zealand, edited by J. M. Soons, pp. 144-160, Longman Paul, Auckland, New Zealand.

Yamagishi, H., and J. Iwahashi (2007), Comparison between the two triggered landslides in Mid-Niigata, Japan by July 13 heavy rainfall and October 23 intensive earthquakes in 2004, Landslides, 4, 389-397.

O. Korup, Research Department Avalanches, Debris Flows, and Rock Falls, Swiss Federal Research Institutes WSL/SLF, CH-7260 Davos, Switzerland. (korup@slf.ch) 